\title{
Are analyst stock recommendation revisions more informative in the post-IFRS period?
}

\author{
Andreas Charitou ${ }^{*}$ \\ Irene Karamanou \\ Anastasia Kopita
}

\begin{abstract}
This paper investigates whether the mandatory IFRS adoption has affected the informativeness of analyst recommendation revisions in Europe. Although prior studies document that IFRS adoption improved analyst forecast attributes, the impact of IFRS can't be completely assessed without examining how the market reacts to informationrich events in an environment with enhanced disclosure. To examine this question we utilize a difference-in-differences design using as main control sample firms that had voluntarily adopted IFRS before the EU's mandated switch. Overall, our evidence suggests that after the mandatory adoption of IFRS both analyst upgrades and downgrades are more informative. These results hold after controlling for a number of variables that capture analyst, firm and information environment characteristics and are robust to a number of sensitivity analyses including the use of a US control sample. Finally, we examine whether our results are sensitive to the level of accounting enforcement. We find that analyst downgrades are more informative in the post-IFRS period for firms in both high and low enforcement environments. Analyst upgrades, however, are more informative only if they are issued for firms in high enforcement countries.
\end{abstract}

Keywords: IFRS, recommendations, enforcement, financial analysts, informativeness 


\section{Are analyst stock recommendation revisions more informative in the post-IFRS period?}

\section{Introduction}

The 2005 mandatory adoption of International Financial Reporting Standards (IFRS) aimed to enhance the comparability of financial statements, improve corporate disclosure, and increase the quality of financial reporting (Regulation (EC) No. 1606/2002). In their 2002 joint white paper, KPMG International and Goldman Sachs asserted that the impact of IFRS adoption in Europe would enhance transparency by requiring companies to disclose new and different aspects of their businesses. This expectation is also reflected in a study conducted by KPMG in 2005 which showed that nearly $77 \%$ of financial analysts surveyed believed that the introduction of IFRS would have an impact on company valuation. Whether this enhanced transparency will also increase the informativeness of analyst stock recommendations is, however, not a priori clear. Even though the literature shows that analyst earnings forecasts exhibit more accuracy after the mandated IFRS adoption, this result may be more related to IFRS earnings exhibiting greater persistence and predictability, than providing value relevant information. Ultimately, how investors react to the release of analyst recommendation revisions in the post-IFRS period depends on whether analysts rely on IFRS financial statements to release more informative recommendations. However, evidence suggests that analysts rely more on their private communication with firm management than on the financial statements themselves as an input to their stock recommendations (Brown, Call, Clement and Sharp, 2015), in turn suggesting that IFRS may not be that useful to analyst research. Thus, whether the informativeness of analyst stock recommendation revisions has been affected by the 
mandatory adoption of IFRS is still an open question and an important one to answer in order to more comprehensibly assess the impact of the mandatory IFRS adoption in Europe.

Our main dataset consists of 9,992 recommendation revisions for EU firms that mandatorily switched to IFRS with 5,408 $(4,584)$ revisions issued in the pre- (post-) IFRS period. To mitigate concerns that our results are affected by events other than those associated with the mandated IFRS switch (Hail and Leuz, 2007), our methodological design implements a difference-in-differences approach. Specifically, we benchmark the analysis, first on a sample of firms that had voluntarily adopted IFRS and second on a sample of US firms. Because firms included in the control samples either use IFRS both before and after mandatory adoption, or do not use IFRS at all, the informativeness of their stock recommendations can only be affected by concurrent economic and regulatory changes, enabling us to effectively control for potential confounding events. An important concern in related research is whether documented changes in the post IFRS period are indeed due to the adoption of IFRS or instead affected by concurrent changes in the institutional environment and, more specifically, in the country's enforcement levels (Soderstrom and Sun, 2007; Christensen, Hail, and Leuz, 2013). The use of a control sample comprising of voluntary adopters, in particular, helps alleviate such concerns since, to the extent that disclosure quality of voluntary adopters is also enhanced in the period following the mandated IFRS switch, differences between the two samples should be more difficult to document, decreasing, in turn, our ability to find evidence in support of our expectations. 
Our results suggest that the market reaction to recommendation revisions for mandatory adopters is stronger in the post-IFRS period. Specifically, the three-day abnormal return around the issuance of the revision is more positive for upgrades and more negative for downgrades, indicating that the 2005 mandatory adoption of IFRS increased the informativeness of analyst stock recommendations. When we condition the analysis on the level of accounting enforcement ${ }^{1}$ we find that the increase in informativeness for stock upgrades is only observed in strong enforcement environments, consistent with related research (see for example, Landsman, Maydew and Thornock, 2012). Interestingly, we find that downgrades are more informative in both strong and weak enforcement environments but the increase in informativeness is greater when country enforcement is strong. We explain these results based on research suggesting that managers face incentives to delay or even conceal poor performance (Kothari, Shu and Wysocki, 2009; Leuz, Nanda and Wysocki, 2003). The existence of these incentives suggests that the disclosure of good news is deemed reliable only when accounting standards are rigorously enforced. On the other hand, bad news can be reliable even if additional mandated disclosures are loosely applied.

Our results are robust to an array of sensitivity analyses. For example, we conjecture that if indeed the driving force behind the increased informativeness of analyst recommendation revisions is related to IFRS, revisions released shortly after earnings announcements should be more informative than those released further away. Results are consistent with this expectation. We also find that our results are not sensitive to: (a) the

\footnotetext{
${ }^{1}$ The country enforcement measure used in this study is the auditing and accounting enforcement measure in Brown, Preiato and Tarca (2014). For brevity purposes we refer to this measure as accounting enforcement.
} 
exclusion from the control sample of voluntary adopters from low enforcement environments, (b) the exclusion of UK firms, and (c) the use of an alternative measure of country legal enforcement based on Kaufmann, Kraay, and Mastuzzi (2007).

Our evidence makes a number of important contributions to the literature. First, we contribute to the IFRS literature by examining the effect of the mandatory IFRS switch on one of the most important financial research outputs: stock recommendations. The literature has shown that analyst stock recommendations elicit significant returns when they are released and that their information content is not subsumed by the information content of other types of analyst research output. Therefore, whether stock recommendation revisions will be more informative can't be automatically presumed from evidence documenting improvements in analyst forecast properties. In addition, and unlike studies which examine the IFRS effects on analyst forecast properties, examining their effect on the informativeness of analyst recommendations changes the focus of the question from the analyst to the investors themselves. Prior research documents that IFRS adoption is associated with greater analyst forecast accuracy, (Byard, Li and $\mathrm{Yu}, 2011$; Horton, Serafeim and Serafeim, 2013), yet it does not directly follow that the increase in analyst accuracy also reflects increased forecast informativeness; it is possible, for example, that reported earnings are less volatile under IFRS, increasing, in turn, the ability of analysts to forecast future earnings more accurately. Such increase in accuracy, therefore, does not necessarily imply an increase in the information content of the forecasts.

Second, our results provide new insights to the results of related research. By showing that mandatory IFRS adoption is also associated with more informative analyst research 
we complement the results of prior research which suggests that IFRS adoption is associated with increases in the quality of firm disclosures. These results are of paramount importance, given the central role analysts play in capital markets. From the standpoint of regulators this result should be of particular importance as the impact of IFRS adoption can't be completely assessed without examining how it affects investor behavior. Our evidence also contributes to the ongoing debate in the accounting literature of whether accounting quality is determined by accounting policies themselves or rather by the country's institutional factors (see for example, Ball, Kothari and Robin, 2000), as it suggests that the sign of the news is important when assessing the relative importance of accounting standards in determining accounting quality. Specifically, in the presence of bad news, the move to IFRS alone can help improve the information environment at least when this is captured by the informativeness of analyst stock recommendation revisions. Accounting enforcement on the other hand, plays a significant role in safeguarding the quality of information when positive news is conveyed.

The remainder of the paper is organized as follows: Section 2 discusses related literature and provides a framework for developing the study's basic expectations. Section 3 presents the methodology and describes the data, Section 4 discusses the empirical results, Section 5 provides sensitivity analysis results and Section 6 concludes.

\section{Related research, contribution and hypotheses development}

\subsection{Related Research and Contribution}

The mandated adoption of IFRS in Europe aimed to increase investor protection as evidenced by the following quote from the European Union's directive 1606/2002: "This 
Regulation has as its objective the adoption and use of international accounting standards in the Community with a view to harmonising the financial information presented by the companies referred to in Article 4 in order to ensure a high degree of transparency and comparability of financial statements and hence an efficient functioning of the Community capital market and of the Internal Market." Thus, the expected benefits of the mandatory adoption in the EU relate to increased disclosure quality and comparability. IFRS research has consistently provided evidence in support of this conjecture. The benefits of the mandatory switch to IFRS include increases in market liquidity and decreases in cost of capital (Daske, Hail, Leuz and Verdi, 2008; Li, 2010), greater institutional or foreign investment (Florou and Pope, 2012; DeFond, Hu, Hung and Li, 2011), and higher information content of earnings (Landsman et al., 2012). Finally, a few papers examine whether IFRS adoption affected analyst research by looking at its effects on analyst earnings forecasts with most of these documenting improvements in properties of analyst earnings forecasts (Byard et al., 2011; Tan, Wang and Welker, 2011; Horton et al., 2013). Preiato, Brown and Tarca, (2015), however, fail to find strong evidence that the mandatory or voluntary adoption of IFRS improved either analyst forecast accuracy or forecast dispersion, while Tan et al. (2011) fail to find an increase in forecast accuracy for local analysts. In light of the mixed results of research on the effects of IFRS adoption on analyst forecasts in particular, examining its effects on stock recommendations is especially important in order to better assess the impact of the IFRS switch on analyst research.

Examining the impact of IFRS on the informativeness of analyst recommendation revisions is important for a number of other reasons as well. First, stock 
recommendations are one of the most important components of financial analyst research output eliciting strong market reactions around their release, (Stickel, 1995; Womack, 1996; Barber, Lehavy, McNichols, Trueman, 2001, 2003, 2006; Jegadeesh and Kim, 2006; Chen and Cheng, 2005, Howe, Unlu, and Yan, 2009), even in the period after twelve of the largest investment banks settled with the SEC on grounds of biased analyst research (Kadan, Madureira, Wand and Zach, 2009).

Second, empirical evidence also suggests that the information content of stock recommendations and their revisions is not entirely subsumed by information contained in any other type of analyst research output. For example, Francis and Soffer (1997) provide evidence that after controlling for earnings forecast revisions, the level and the revision in stock recommendations explain a significant part of the variation in abnormal returns, indicating their incremental explanatory power beyond the information conveyed by earnings forecasts. Asquith, Mikhail and Au, (2005) extend the results of Francis and Soffer (1997) and find that recommendation upgrades (downgrades) are associated with positive (negative) market reactions after controlling for the information content of earnings forecasts and price targets. Similarly, Brav and Lehavy (2003) show that recommendations and earnings forecast revisions are informative in the presence of target prices. In addition, literature suggests that the informativeness of analyst forecasts differs from that of stock recommendations as individual investors seem to have difficulty comprehending the meaning of the former but literally rely on analyst stock recommendations without accounting for possible biases (Malmendier and Shanthikumar, 2007; Mikhail, Walther and Willis, 2007). Overall, extant evidence suggests that the information content of analyst stock recommendations is, at least to some extent, unique, 
further highlighting the need to examine the impact of IFRS on analyst stock recommendations.

Third, looking at recommendations enables us to examine how the effects of IFRS adoption on analyst research quality affect investor reliance on this research. This is an important question to answer since analysts are important market intermediaries whose main goal is to disseminate information to the market. Even though a number of studies examine whether the IFRS switch affects analyst forecast properties, (e.g., Byard et al., 2011; Preiato et al., 2015), how the market will react to the information embedded in analyst reports cannot be discerned from the results of this research. Even under the assumption that IFRS adoption is associated with increased forecast accuracy, (see for example, Byard et al., 2011; Ashbaugh and Pincus, 2001), differences in the information content of forecasts and recommendations suggest that it is not clear whether this increased forecast accuracy will also translate to increased recommendation informativeness. This is also the case since IFRS adoption may be associated with increased forecast accuracy not so much because IFRS convey more information about the firm but because IFRS earnings are less volatile and hence more predictable. Tan et al. (2011), also acknowledge this possibility: “Opponents also criticize IFRS for allowing too much judgment in fair value measurements... If this subjectivity results in increased earnings smoothing, then analyst following could decline due to the diminished usefulness of accounting data, but forecast accuracy could improve” (p.1309). Thus, even though IFRS adoption has been associated with increased forecast accuracy whether it also increased the informativeness of analyst research is still an open research question. A complete assessment of the effects of IFRS adoption on financial analyst research can't 
therefore be achieved without examining how investors perceive and react to analyst reports.

Finally, examining the informativeness of analyst stock recommendation revisions also allows to condition the analysis on the direction of the information revealed, i.e., whether the revision conveys good vs. bad news. Related literature documents that the informativeness of downgrades is generally greater than that of upgrades (Womack, 1996; Kadan et al., 2009), offering two broad explanations for this result. First, a number of incentives motivate firms to avoid or delay the disclosure of bad news. Kothari et al. (2009), for example, document higher price reactions for bad news disclosures indicating that management successfully withholds bad news until it is inevitably released. The survey results of Graham, Harvey, and Rajgopal (2005), support this conclusion, by providing evidence that managers delay bad news in the hope they may never have to disclose it if firm performance improves in the future. Second, analysts face incentives to issue optimistic recommendations for the firms they follow due to career concerns, the desire to increase their employers' revenue from trading commissions or investment banking deals (e.g. Dugar and Nathan 1995, Hong and Kubik 2003, Brown et al., 2015), and to secure access to the management of the firm (Chen and Matsumoto, 2006), resulting in weaker market reactions to upgrades than downgrades (Kadan et al., 2010). Together, extant evidence suggests that the information content of analyst recommendations is related to their favorableness and hence examining the impact of IFRS on the informativeness of analyst research cannot be fully assessed unless the analysis allows for the differential impact of IFRS on upgrades and downgrades. 


\subsection{Hypotheses Development}

The above discussion highlights the importance of financial analysts as the main source of information for investors, a result that is strongly supported by anecdotal evidence as well. According to the SEC, analysts promote "the efficiency of our markets by ferreting out facts and offering valuable insights on companies and industry trends." (Securities and Exchange Commission, 2010).

If the markets rely mostly on analyst reports for information it is not unreasonable to expect that the informativeness of analyst reports will be increasing with the reliability and quality of firm provided information. The limited literature examining this relation offers support for this conjecture. The model in Abarbanell, Lanen and Verrecchia (1995), under the assumption that private information acquisition is endogenous, predicts that information precision increases forecast informativeness. Frankel, Kothari and Weber (2006) find that the informativeness of analyst forecasts is positively related to the timeliness of financial information corroborating the results in Francis, Schipper and Vincent (2002) who find that more informative earnings announcements add to the informativeness of subsequent analyst reports.

Based on the evidence in the literature suggesting that the adoption of IFRS enhances the information environment of the firm, we posit that the mandatory adoption of IFRS will render analyst recommendation revisions more reliable, increasing, in turn, their informativeness. Hypothesis 1, stated in the alternative form, is therefore the following:

H1: The informativeness of analyst recommendation revisions is greater in the period after the mandatory adoption of IFRS. 
Yet, the vast majority of previous studies also find that IFRS benefits are more pronounced, if not confined, in countries with strong legal or accounting enforcement. These results are consistent with the conjecture that the implementation of accounting standards is affected by the country's institutional environment. Daske et al. (2008), for example, find that IFRS adoption is related to increased market liquidity and firm values and decreased costs of capital, but these results hold only for firms in countries with strong legal enforcement. Similarly, Li (2010) finds a significant reduction in the firms' cost of equity capital, while Byard et al. (2011) find that forecast accuracy is increased after the mandatory IFRS adoption, but both results hold only for firms in strong legal enforcement environments. A number of other papers document that the benefits of IFRS adoption apply to firms with low enforcement but that these benefits are stronger if the country enforcement level is high. Beuselinck, Joos, Khurana, and Van der Meulen (2010) find that the increase in stock price informativeness following IFRS adoption is stronger in countries with strong legal enforcement while Landsman et al. (2012) document that IFRS adoption increases the information content of earnings announcements, but that this effect is stronger in the presence of strong enforcement. Similarly, André, Filip, and Paugam (2015), find that in countries with weak audit and accounting quality the introduction of IFRS results in lower conditional conservatism, but that this effect is less pronounced in high enforcement countries, consistent with a more appropriate application of conditional conservatism principles. ${ }^{2}$

\footnotetext{
${ }^{2}$ Preiato et al. (2015) also examine whether accounting enforcement is related to lower forecast errors. Even though they find little evidence that the mandatory and voluntary use of IFRS is associated with lower errors once they control for the degree of enforcement, their models don't include interactions between the enforcement variables and the use of IFRS. Therefore, it is not clear whether such a relation would be evident in high enforcement countries.
} 
Our second hypothesis is therefore based on the consistent evidence in the literature that the reliability of the application of IFRS is related to the country's enforcement level. If the informativeness of analyst research increases with the quality of firm disclosures, the informativeness of analyst recommendations in the post-IFRS period will be greater in high-enforcement countries. Hypothesis 2, stated in the alternative form, is thus the following:

H2: The informativeness of analyst recommendation revisions is greater in the period after the mandatory adoption of IFRS for firms domiciled in high enforcement countries.

\section{Methodology and Data}

One major concern when examining the impact of mandatory IFRS adoption is the difficulty in separating the financial effects of IFRS from the effects of other possible concurrent market changes that are unrelated to financial reporting. To address this concern we employ a control sample that comprises of European firms that had voluntarily adopted IFRS prior to the European-wide mandated switch to IFRS (see for example, Horton et al., 2013; Byard et al., 2011; Tan et al., 2011; Wang, Young, and Zhuan, 2008). Changes in the informativeness of recommendation revisions for voluntary adopters around the 2005 mandated IFRS adoption event can still be observed if a) the informativeness of analyst recommendation revisions is affected by events unrelated to the IFRS mandated switch or b) the mandatory adoption results in a more rigorous application of IFRS by voluntary adopters (Christensen et al., 2013; Daske et al., 2008, 
2013). ${ }^{3}$ As discussed in section 5.5 results are qualitatively unchanged when the control sample excludes voluntary adopters from countries with lax enforcement.

\subsection{Research Design}

To examine the effect of the mandatory IFRS adoption on the informativeness of analyst stock recommendations revisions, we run model (1) below, which employs a differencein-differences approach between mandatory and voluntary IFRS adopters. All analyses are performed separately for the sub-samples of recommendation upgrades and downgrades (see among others, Barber, Lehavy, and Trueman, 2007; Ivkovic and Jegadeesh, 2004; Barber et al., 2006).

$C A R=\{P O S T 2005$, MAND, POST2005*MAND, FOLL, DISPRESION, AVG_SURPRISE, TOPBROKER, EXPERIENCE, REC_CD, SAME_EPS_CH, MOMENTUM, M_B, SIZE, Country effects, Industry effects\}

Following related research, the informativeness of analyst recommendations is captured by the market reaction around their release. $C A R$ is cumulative abnormal returns over the three day window around the recommendation announcement. Daily abnormal returns are adjusted for risk based on the market model estimated using daily returns from 265 to 15 days before the recommendation announcement. Model errors are clustered by event date to mitigate the effects of event overlapping.

POST2005 is an indicator variable which equals 1 if the recommendation revision is issued in the period after the mandatory adoption of IFRS, (post-IFRS period), and zero

\footnotetext{
${ }^{3}$ The use of voluntary adopters in the control sample has the added advantage that these firms reside in the same countries as the treatment firms alleviating concerns that inferences may be affected by the different institutional and legal environments the two samples operate in. In section 5.2 we drop this requirement and report results using US firms as the control sample.
} 
otherwise. We include recommendations that are issued during the 2005 calendar year in the pre-IFRS period as the full impact of IFRS disclosure can only be observed after the release of firm annual reports. Moving the cutoff date back to 30 June, 2005 to account for changes in disclosure of interim reports does not affect inferences (untabulated).

$M A N D$ is a dummy variable that takes the value 1 for mandatory and 0 for voluntary adopters. If the change in the recommendation informativeness of mandatory adopters is due to other concurrent regulatory or market-wide events, the informativeness of stock recommendations for voluntary adopters should be similarly affected. In this case, the coefficient on POST2005*MAND should not be significantly different from the coefficient on POST2005 which captures the change in the informativeness of recommendations for the control sample of voluntary adopters. More importantly, a significant coefficient on $P O S T 2005 *$ MAND would suggest that the informativeness of stock recommendations for mandatory adopters is different between the pre- and postIFRS periods.

The model controls for a number of variables that are expected to affect the informativeness of analyst stock recommendation revisions. The first set of variables captures the richness of the firm's information environment. We expect that analyst upgrades and downgrades should be more value relevant when the firm's information environment is poor. Following Lang and Lundholm, (1996), who show that analysts tend to follow firms with more informative disclosures, we first capture the firm's information environment with analyst following, FOLL. FOLL is measured as the natural logarithm of the number of analysts that have issued at least one recommendation up to the month prior to the recommendation date. Second, the model also controls for the 
overall uncertainty in the firm's information environment, captured by the dispersion in analyst earnings forecasts (Lang and Lundholm, 1996; Irani and Karamanou, 2003). DISPERSION, is calculated as the standard deviation of all annual earnings forecasts issued before the recommendation month. Finally, the model controls for earnings forecast error, AVG_SURPRISE, measured as the absolute value of the difference between actual earnings and the most recent consensus earnings forecast scaled by the absolute value of actual earnings. We posit that analyst forecast errors will be greater when the information environment of the firm is poor. Zhang (2006) finds that information uncertainty is related to larger forecast errors, while Hope (2003) documents that analyst forecast accuracy is positively related to the quality of firm-level disclosures.

Our second set of variables controls for the characteristics of the analyst issuing the recommendation. TOPBROKER is an indicator variable taking the value 1 if the recommendation is issued by one of the top 10 brokerage firms based on the rankings of the Institutional Investor magazine. Institutional Investor's "All Europe Research Team" rankings are based on surveying the directors of research and heads of investments at institutions worldwide evaluating. These professionals evaluate each research team based on important attributes, the three most important of which are industry knowledge, integrity and local market knowledge. Barber et al. (2006) find that recommendation announcement returns are greater for larger brokerage houses while Park and Stice (2000) find that superior analyst forecasts have a greater impact on market prices. Similarly, Gleason and Lee (2003) find that forecasts by Institutional Investor All-Star analysts elicit a stronger immediate price response while Loh and Stulz (2011) find that recommendations issued by leader and star analysts are more likely to be influential. We, 
thus, expect a stronger market reaction for recommendation revisions issued by the top 10 investment banks. Furthermore, prior literature finds that analysts become better as they gain experience. Mikhail et al. (2007), for example, show that analyst forecast accuracy increases with experience and that the market places more weight on experienced analyst forecasts. We capture the level of the analyst's experience, EXPERIENCE, by the number of years in which the analyst issued at least one earnings forecast for the firm.

Our third set of variables captures the informativeness of the recommendation itself. First, we expect that the level of the recommendation revision, $R E C_{-} C D$, should be related to the market's reaction. We retain the IBES ranking system which is based on 5 distinct recommendation categories with 1 denoting strong buys and 5 strong sells and expect that for upgrades (downgrades) lower (higher) values of the recommendation rating should result in a more positive (negative) market reaction. Second, to control for confounding effects related to the informativeness of concurrent earnings forecast announcements the model includes an indicator variable, SAME_EPS_CH, that takes the value 1 if the recommendation revision is accompanied by an earnings forecast revision that moves in the same direction. Francis and Soffer (1997) find that price reactions to recommendation announcements are enhanced by same-sign evidence from a forecast revision while Kecskés, Michaely, and Womack (2017) find that recommendations accompanied by earnings forecasts elicit greater market reactions. We thus expect the coefficient on SAME_EPS_CH to be positive for upgrades and negative for downgrades.

Finally, the model includes a number of variables that are related to market returns. We use the market-to-book ratio, $M_{-} B$, to control for firm growth opportunities and the natural logarithm of total assets to control for firm size, SIZE. Jegadeesh, Kim, Krische 
and Lee, (2004) find that analysts tend to recommend smaller and high growth stocks while Loh and Stulz (2011) find that recommendations issued for growth and small firms are more influential. Price momentum, MOMENTUM, is calculated as the compounded daily market-adjusted return in the period from 90 days to 1 day before the recommendation announcement. We use price momentum to control for any other information available to the market which can induce analysts to revise their recommendations (see for example, Jegadeesh et al., 2004).

\subsection{The effect of accounting enforcement}

To examine whether the informativeness of stock recommendations is affected by the country's level of accounting enforcement, we utilize the enforcement measure developed by Brown et al. (2014) which more closely captures the country's degree of compliance with accounting standards as promoted by external audit and independent enforcement bodies. For this analysis, we replace country fixed effects in model (1) with $A C C T \_E N F$, which takes the value 1 for countries with high accounting enforcement and 0 otherwise. The cutoff value is based on our sample's median of the AETOTAL variable in Brown et al. (2014). To examine whether the relation between increased disclosure and the informativeness of recommendation revisions is affected by enforcement levels, we interact ACCT_ENF with POST2005 and, following Landsman et al. (2012), we restrict the sample to mandatory adopters. In this model specification, we also control for two additional country characteristics. First, the importance of the capital market is captured by the ratio of market capitalization as a percentage of GDP, $M C_{-} G D P$. Second, the difference between IFRS and local GAAP, DIFF_ACCT, is a dummy variable that takes the value 1 for firms domiciled in countries with difference between IFRS and local 
GAAP above the sample median, and 0 otherwise. The country values for this variable are based on gaap_diffl obtained from Bae, Tan and Welker (2008), where higher values of gaap_diffl indicate greater differences.

\subsection{Data}

To construct our sample we obtain all recommendations in the IBES database for the period 2003 - 2007 for all European firms. ${ }^{4}$ We eliminate recommendations that are issued within seven days before the earnings announcement to ensure that the observed market reaction around the recommendation is not related to the forthcoming announcement. Following related research, we focus on recommendation changes but we also require that for each firm in the sample there is at least one recommendation revision in both the pre- and post- IFRS periods. This technique alleviates any concerns that the change in sample composition may confound results. ${ }^{5}$ Daily returns to construct $C A R$ and MOMENTUM and variables to construct $M_{-} B$ and SIZE and to identify the control sample of voluntary adopters are obtained from Datastream. Analyst information to compute FOLL, REC_CD, SAME_EPS_CH, DISPERSION, AVG_SURPRISE, and EXPERIENCE is obtained from IBES. Data to compute $M C \_G D P$ are obtained from The World Bank, and data to identify the top 10 investment banks from Institutional Investor's “All-Europe Research Team” for each sample year.

These data requirements result in a final sample of 9,992 recommendation changes issued for a total of 348 firms. Panel A of table 1 shows the distribution of the mandatory and

\footnotetext{
${ }^{4}$ Since this study examines the informativeness of analyst recommendations around an event, extending the period under review does not offer any advantage, while at the same time runs the risk of later events, such as the onset of the financial crisis, altering results and affecting inferences.

${ }^{5}$ In section 5.3 we discuss results when this requirement is dropped.
} 
voluntary recommendation samples, separately for upgrades and downgrades, across the two sub-periods. From the 5,051 upgrades in the sample 4,130 pertain to mandatory and 921 to voluntary adopters. Similarly, from the 4,941 downgrades 4,047 relate to mandatory and 894 to voluntary adopters. Panel B of the same table shows the distribution of the sample across country of origin for both the mandatory and voluntary samples. According to the panel the country with the highest representation in the mandatory sample is the Netherlands with a representation of $17.08 \%$, followed by Sweden $(15.51 \%)$ and the UK (15.43\%). We therefore do not observe a major concentration in observations from a specific country for the mandatory sample. In contrast, the main voluntary sample comprises mostly of firms from Germany $(58.79 \%)$, and Finland (20.06\%).

\section{Empirical Results}

\subsection{Univariate analysis}

Panels A and B of Table 2 present mean and median values of all explanatory variables in the pre- and post- IFRS periods, separately for the subsamples of upgrades and downgrades. The significance of the difference in means and medians is based on a t-test and a Wilcoxon test, respectively. Results in table 2 suggest a number of important changes in the information environment and firm characteristics across the two periods for the mandatory and voluntary samples. Specifically, for the mandatory sample, results indicate that in the post-IFRS period upgraded firms exhibit lower analyst following but also lower dispersion and lower forecast error. Similarly, downgraded firms also exhibit a decrease in analyst following and analyst forecast error after the mandatory adoption of 
IFRS. Interestingly, none of these analyst attributes changes significantly in the same period for the voluntary sample. These results suggest that the mandatory adoption of IFRS has differentially affected the information environment of the mandatory and voluntary samples. Results in Table 2 also indicate a number of changes that affect mandatory and voluntary adopters in a similar manner. First, in the post-IFRS period, analyst upgrades are more favorable as evidenced by the lower values of $R E C_{-} C D$ and are preceded by lower price momentum. In addition, when in the post-IFRS period analysts upgrade firms they are also more likely to revise their earnings forecasts in the same direction. Results also suggest that in the post-IFRS period issuing analysts have greater experience but are also less likely to work for top-brokers. Results also indicate that in the post-IFRS period, analysts tend to both upgrade and downgrade firms a) from countries whose local accounting standards exhibit greater differences from IFRS, and b) with more important capital markets. Finally, for both mandatory and voluntary samples, analysts are more likely to upgrade firms from weak accounting enforcement environments but the opposite is true for downgrades. Correlation analysis, (untabulated), corroborates these results. Overall, preliminary univariate analysis findings suggest that the information environment of both mandatory and voluntary adopters has been affected by the mandatory IFRS switch.

Table 3 compares the market reaction around recommendation revision announcements between the two sub-periods for both the mandatory and voluntary samples. Panel A presents results for recommendation upgrades and panel B for downgrades. Results suggest that for the mandatory sample an upgrade elicits a mean (median) market response of $0.551 \%(0.35 \%)$ in the pre- IFRS period and $1.415 \%(0.97 \%)$ in the post- 
IFRS period. This is equivalent to an increase in mean (median) CAR of $0.864 \%(0.63 \%)$ between the two periods, which is both statistically and economically significant. In contrast, recommendation upgrades for the voluntary sample do not exhibit significant changes between the two periods. Specifically, the mean (median) market reaction to a recommendation upgrade in the pre-IFRS period elicits a market response of $0.91 \%$ $(0.78 \%)$ insignificantly changing by $0.04 \%(-0.01 \%)$ in the post-IFRS period. Results also suggest that even though analyst upgrades are more informative for the voluntary than the mandatory sample in the pre-IFRS period, in the post-IFRS period this difference is eroded based on median returns and even reversed based on mean returns.

The market reaction to downgrades for mandatory adopters follows a similar pattern. Specifically, even though a downgrade in the pre- IFRS period elicits a mean (median) market reaction of $-0.63 \%(-0.45 \%)$, such reaction more than doubles in the post-IFRS period to $-1.52 \%(-1.08 \%)$, reflecting a statistically and economically significant difference of $-0.88 \%(-0.63 \%)$. In contrast, the mean (median) market reaction to analyst downgrades for the voluntary sample does not become more negative in the post-IFRS period. Importantly, while in the pre-IFRS period the mean (median) reaction to downgrades for the voluntary sample is significantly more negative than that of the mandatory sample this difference disappears in the post-IFRS period.

Correlation analysis corroborates the above findings. Specifically, untabulated results suggest that for upgrades (downgrades) the correlation between CAR and POST2005 is strongly positive (negative), consistent with recommendation revisions exhibiting greater information content for mandatory adopters in the post-IFRS period. Interestingly, neither of these correlations is significant for the voluntary sample. Taken together, the results of 
the univariate analysis are consistent with an increase in the informativeness of both upgrades and downgrades for mandatory IFRS adopters. Multivariate regression results which control for differences in firm and analyst characteristics across the two samples are presented in the next section.

\subsection{Regression results}

Panel A of Table 4 presents the results of equation (1) for recommendation upgrades and panel B for downgrades. ${ }^{6}$ Given that all models contain fixed effects the model intercepts cannot be interpreted and therefore are not shown. In both panels, the first model includes industry and country fixed effects whereas in the second model fixed country effects are dropped and replaced by country variables. To eliminate the effects of event overlapping, model residuals are clustered by the date of the recommendation revision release. In both models of panel A the coefficient on the interaction between the POST2005 and MAND is positive and statistically significant, suggesting that in the post-IFRS period analyst upgrades for mandatory adopters elicit a more positive market reaction compared to the pre-IFRS period. This increase in $C A R$ is economically significant as well, approaching $0.9 \%$ in both models. In addition, the coefficient on MAND suggests that in the pre-IFRS period upgrades for mandatory adopters elicit a market reaction of $0.37 \%(p$-value $=0.09)$ and $0.42 \%$ (p-value $=0.03$ ) lower than that of voluntary adopters. Interestingly, none of the models of panel A suggests a similar increase in $C A R$ for the control sample as evidenced by the insignificant coefficient on POST2005.

\footnotetext{
${ }^{6}$ Results are presented after the elimination of outliers at $1 \%$ based on the studentized residual.
} 
Similar to the findings for the upgraded sample, results for recommendation downgrades suggest a more negative market reaction in the post-IFRS period for mandatory adopters. Specifically, in both models of panel B, the coefficients on the interaction between POST2005 and MAND are negative and strongly significant with values more negative than $-1.2 \%$. The positive and significant coefficient on MAND suggests that in the preIFRS period downgrades for mandatory adopters are less informative than those issued for the voluntary sample, while the insignificant coefficients on POST2005 suggest that the informativeness of analyst downgrades for firms that had already adopted IFRS voluntarily does not exhibit a significant change.

The results on the control variables corroborate those of the univariate analysis to a great extent. Specifically, results suggest that a rich information environment, as captured by analyst following, decreases the informativeness of upgrades. In addition, upgrades issued by more experienced analysts or analysts at top investment banks are deemed more reliable by the market since they elicit a greater market reaction. In addition, the magnitude of the news also affects the informativeness of upgrades. We find that upgrades to lower, (i.e., more favorable), rankings and upgrades that are accompanied by a consistent revision in earnings forecasts are more informative. We also find that recommendation upgrades are more informative for high growth firms as reflected by the positive and significant coefficient on $M_{-} B$ and for firms with lower price momentum. Finally, results in model 2 also suggest that the market reaction to upgrades is greater for firms in countries with stronger accounting enforcement. Overall, we interpret these results as indicating that recommendation upgrades are more informative when the information they convey is less anticipated and when they are deemed more reliable. 
These results are broadly consistent with the results in Loh and Stulz (2011) who find that recommendation changes are more influential when they are issued for small firms, firms with lower Book-to-Market ratios, and lower analyst activity. They also find that recommendations issued by leader analysts and which are accompanied by earnings forecasts are also more informative.

Turning to panel $\mathrm{B}$ we find that analyst experience and the contemporaneous release of a negative forecast revision are associated with greater informativeness for analyst downgrades as well. In addition, results suggest that the informativeness of downgrades decreases with MOMENTUM, $M \_B$, and SIZE. The first model of panel B also suggests that the informativeness of downgrades increases with analyst following but this result is not obtained in model (2). We posit that in the downgraded sample SIZE captures most of the information effect reflected in analyst following, as evidenced by the high correlation between the two variables $(\rho=0,77)$. This result is consistent with the evidence in Barber et al. (2001), Stickel (1995), Womack (1996), and Loh and Stulz (2011), who find that the market reaction to recommendations is significantly stronger for smaller firms. The positive relation of MOMENTUM with CAR suggests that downgrades are deemed more informative when they reaffirm poor return performance. Finally, and similarly to the upgraded sample, downgrades are more informative when issued for firms in high enforcement environments.

In panel $\mathrm{C}$ we allow the relations between $\mathrm{CAR}$ and the control variables to differ between the mandatory and voluntary sample by presenting separate regressions for the two groups. Results corroborate the main findings for both the upgraded and downgraded sample. In particular, for the mandatory sample the coefficient on POST2005 is 
significantly positive (negative) for analyst upgrades (downgrades), suggesting an increase in the informativeness of analyst recommendation revisions after the mandatory IFRS adoption. Interestingly, we do not find any significant change in the informativeness of analyst recommendation revisions for the voluntary sample. In addition, the difference in the coefficients on POST2005 between the mandatory and voluntary samples is significantly more positive (negative) for analyst upgrades (downgrades). Together the results provide consistent and strong evidence that analyst recommendation changes are more informative for mandatory adopters in the post-IFRS period.

We next examine whether the country level of accounting enforcement affects the association between the IFRS mandatory adoption and the documented increase in the informativeness of analyst recommendation revisions. Following Landsman et al. (2012) we focus our attention on the mandatory sample and interact POST2005 with ACCT_ENF. Model 1 (model 2) of Table 5 presents findings for recommendation upgrades (downgrades). First, and consistent with prior research, results indicate that upgrades are more informative in the post-IFRS period but only if they are issued for firms domiciled in countries with high accounting enforcement, as suggested by the positive and significant coefficient on the interaction of POST2005 with ACCT_ENF and the insignificant coefficient on POST2005. With respect to downgrades, the negative and significant coefficient on POST2005 suggests that downgrades are more informative in the post-IFRS period for firms in low accounting enforcement environments. The negative and significant coefficient on the interaction between POST2005 and $A C C T \_E N F$ suggests, however, that the increase in informativeness is even greater for 
firms domiciled in countries with strong accounting enforcement. We explain these results based on research suggesting that managers face incentives to conceal poor performance, (Leuz et al., 2003), and hence are reluctant to disclose bad news timely (Kothari et al., 2009). This suggests, that in the presence of these incentives, disclosures of bad news should be informative even in lax enforcement environments, but good news can only be deemed reliable when accounting standards are rigorously enforced.

The above results corroborate those of Table 4, indicating that the informativeness of both upgrades and downgrades increases in the post-IFRS period. Our results also suggest that the enforcement effect documented by prior research depends on the direction of the sign of the news revealed. This is an important result since the majority of related research suggests that the IFRS adoption benefit is confined mostly in high enforcement countries. Our evidence, however, indicates that in the presence of negative news accounting standards per se can increase the quality of accounting disclosures. Charitou, Karamanou, and Lambertides (2015) find that IFRS adoption induces firms to reveal their bad news that were able to conceal under local GAAP and that this effect is present even in low enforcement environments. We extend their results by showing that the negative information revealed is informative to the market, at least as reflected in unfavorable analyst recommendation revisions.

\section{Sensitivity analyses}

\subsection{Recommendation revision informativeness around earnings announcements}

If the increased informativeness of analyst stock recommendations is indeed related to the underlying increase in firm disclosures, the reaction to analyst recommendation revisions 
should be more pronounced in the period immediately following earnings announcements. In Table 6 we examine this conjecture by comparing the informativeness of recommendations issued within 30 calendar days after the earnings announcement to those issued in the rest of the sample period. For the purposes of this analysis, we also add back 354 upgrades and 300 downgrades that were issued 7 days before the earnings announcement. Results suggest that both upgrades and downgrades are informative even when they are issued away from the earnings announcement but, as expected, those that are issued closer to the earnings announcement elicit a more positive and negative market reaction to the recommendation revision, respectively. Our results therefore, provide consistent evidence that the increased transparency of financial reporting after the IFRS mandatory switch increases the informativeness of analyst stock recommendation revisions.

\subsection{Using US firms as control}

Even though our choice of voluntary adopters as control sample is based on the expectation that any confounding events would likely affect firms sharing the same institutional and legal environments in a similar way, we acknowledge that the two samples may differ in important aspects that are difficult to identify and hence to control for. Given that the reliability of inferences is based on the appropriateness of the benchmarking sample we extend the analysis by using US based firms as an alternative control sample. To construct the US control sample we match our European mandatory adopters to US firms based on industry, size and market to book multiples. ${ }^{7}$ Similar to the

\footnotetext{
${ }^{7}$ The control sample consists of all US firms with SIZE and $M_{-} B$ values within $10 \%$ of the respective values of each treatment firm.
} 
main analysis, POST2005 takes the value 1 for recommendation changes announcements issued after 2005, and 0 otherwise. The variable $E U$ takes the value 1 if the recommendation revision is issued for a European firm that mandatorily adopted IFRS, and 0 if the recommendation is issued for a US firm in the control sample.

Table 7 presents results. In general, our findings are in agreement with those of the main analysis presented in Table 4 and suggest that the informativeness of both upgrades and downgrades is higher for mandatory adopters in the post-IFRS period. More importantly, the analysis fails to document a similar increase in the informativeness of recommendation changes for the matching US firms, alleviating concerns that results are driven by other confounding events.

\subsection{Other analyses}

In order to further test the robustness of our results, we run a number of additional tests (not tabulated). First, we examine whether the informativeness of analyst recommendation revisions changes within the pre- or post-IFRS periods. If our results are not affected by confounding events or model specification issues and are indeed associated with the adoption of IFRS we shouldn't find changes in the informativeness of stock recommendations within either of the two sub-periods. Specifically, for the pre (post) period we examine whether notable changes in $C A R$ can be observed around the year 2003 (2006). Results indicate that there are no significant differences in the market reaction around these two alternative cutoff dates.

In the second test we replace the US control sample by the 3-day return of the US value weighted market index for each recommendation date in the treatment sample. This 
method does not rely on any matching procedure to identify suitable US firms and hence does not condition inferences on the matching criteria imposed. We continue to find that in the post-IFRS period the informativeness of upgrades and downgrades is enhanced even when accounting for possible unobserved events that are captured by the return of the US market.

In addition, to examine whether the mandatory IFRS adoption has both direct and indirect effects on the informativeness of recommendation revisions we use a path analysis design similar to that used in Landsman et al. (2012). Specifically, we examine whether analyst following and recommendation lag are mechanisms through which the mandatory IFRS adoption increases the informativeness of analysts' revisions. Using a SEM model approach, the equations include a regression of the outcome variable (absolute 3-day CAR for mandatory adopters) on the mediating variables and all control variables, and regressions of each mediating variable on the source variable. In both cases, we continue to find significant direct effects but results do not provide evidence of any significant indirect effects.

Finally, we also find that our results are not sensitive to: (a) using an alternative measure of country legal enforcement based on Kaufmann et al. (2007), (b) excluding UK firms, (c) excluding from the control sample voluntary adopters from low enforcement countries, (d) using two-day window return for measuring the market's reaction, and (e) dropping the requirement that for a given firm to be included in the sample there has to be at least one recommendation revision in both the pre- and post-IFRS periods. In short, this array of additional tests provides reasonable assurance that our results are robust and inferences are not affected by confounding events. 


\section{Summary and Conclusions}

This study revisits the role of financial analysts in capital markets by examining whether the mandatory switch to IFRS affects the informativeness of their stock recommendation revisions. Prior studies document that IFRS adoption has improved analyst forecast attributes but such evidence does not necessarily translate into greater informativeness. It is possible that this result may be more related to IFRS earnings exhibiting greater predictability rather than providing value relevant information. In light of prior research that suggests that analysts rely more on the private communication with management than the firm's financial information for their research output, it is not a priori clear whether the switch to IFRS will affect the informativeness of recommendation revisions.

Our results suggest that in the post-IFRS period the informativeness of analyst recommendations is enhanced as evidenced by a more positive reaction to analyst upgrades and a more negative reaction to downgrades. When we examine the effect of accounting enforcement on recommendation informativeness we find that both upgrades and downgrades are more informative in the post-IFRS period for high enforcement countries but downgrades are even informative if issued for firms in low enforcement environments. This is an important result since it suggests that the enforcement effect documented by prior research depends on the direction of the news revealed. Our results should be of importance to regulators as their overall assessment on the impact of the mandated IFRS switch cannot be complete without examining how it affects the informativeness of analyst research. 


\section{References}

Abarbanell, J., W. Lanen and R. Verrecchia (1995), “Analysts' Forecasts as Proxies for Investor Beliefs in Empirical Research", Journal of Accounting and Economics 20, 31-60.

André, P., A. Filip and L. Paugam (2015) "The Effect of Mandatory IFRS Adoption on Conditional Conservatism in Europe", Journal of Business Finance \& Accounting 42, 482-514.

Ashbaugh, H. and M. Pincus (2001), "Domestic Accounting Standards, International Accounting Standards, and the Predictability of Earnings", Journal of Accounting Research 39, 417-434.

Asquith, P., M. Mikhail and A. Au (2005), "Information Content of Equity Analyst Reports”, Journal of Financial Economics 75, 245-282.

Bae, K., H. Tan and M. Welker (2008), "International GAAP Differences: The impact on Foreign Analysts", The Accounting Review 83, 593-628.

Ball, R., S. P. Kothari and A. Robin (2000), “The Effect of International Institutional Factors on Properties of Accounting Earnings", Journal of Accounting and Economics 29, 1-51.

Barber, B., R. Lehavy, M. McNichols and B. Trueman (2001), "Can Investors Profit from the Prophets? Security Analyst Recommendations and Stock Returns", The Journal of Finance 56, 531-563.

Barber, B., R. Lehavy, M. McNichols and B. Trueman (2003), "Reassessing the Returns to Analysts' Stock Recommendations”, Financial Analysts Journal 88-96.

Barber, B., R. Lehavy, M. McNichols and B. Trueman (2006), "Buys, Holds, and Sells: The Distribution of Investment Banks' Stock Ratings and the Implications for the Profitability of Analysts' Recommendations", Journal of Accounting and Economics 41, 87-117.

Barber, B., R. Lehavy and B. Trueman (2007), "Comparing the Stock Recommendation Performance of Investment Banks and Independent Research Firms", Journal of Financial Economics 85, 490-517.

Beuselinck, C., P. Joos, I. Khurana and S. Van der Meulen (2010), "Mandatory IFRS Reporting and Stock Price Informativeness", Working paper.

Brav, A. and R. Lehavy (2003), “An Empirical Analysis of Analysts' Target Prices: Short-term Informativeness and Long-term Dynamics", The Journal of Finance 58, 1933-1968.

Brown, L. D., A. C. Call, M. B. Clement and N. Y. Sharp (2015), "Inside the "Black Box" of Sell-side Financial Analysts", Journal of Accounting Research 53, 1-47. 
Brown P., J. Preiato and A. Tarca (2014), "Measuring Country Differences in Enforcement of Accounting Standards: An Audit and Enforcement Proxy", Journal of Business Finance and Accounting, 41, 1-52.

Byard, D., Y. Li and Y. Yu (2011), "The Effect of Mandatory IFRS Adoption on Financial Analysts' Information Environment", Journal of Accounting Research 49, 69-96.

Charitou, A., I. Karamanou and N. Lambertides (2015), "Who are the Losers of IFRS Adoption in Europe? An Empirical Examination of the Cash Flow Effect of Increased Disclosure", Journal of Accounting, Auditing and Finance 30, 150-180.

Chen, X. and Q. Cheng (2006), "Institutional Holdings and Analysts' Stock Recommendations", Journal of Accounting, Auditing \& Finance 21, 399-440.

Chen, S. and D. A. Matsumoto (2006), "Favorable versus Unfavorable Recommendations: The Impact on Analyst Access to Management-Provided Information", Journal of Accounting Research 44, 657-689.

Christensen, H., L. Hail and C. Leuz (2013), "Mandatory IFRS Reporting and Changes in Enforcement", Journal of Accounting and Economics 56, 147-177.

Daske H., L. Hail, C. Leuz and R. Verdi (2008), "Mandatory IFRS Reporting around the World: Early Evidence on the Economic Consequences", Journal of Accounting Research 45, 1085-1142.

Daske H., L. Hail, C. Leuz and R. Verdi (2013), "Adopting a Label: Heterogeneity in the Economic Consequences of IFRS Adoption”, Journal of Accounting Research 51, 495-547.

DeFond, M., X. Hu, M. Hung and S. Li (2011), "The Impact of Mandatory IFRS Adoption on Foreign Mutual Fund Ownership: The Role of Comparability", Journal of Accounting and Economics 51, 240-258.

Dugar, A. and S. Nathan (1995), "The Effect of Investment Banking Relationships on Financial Analysts' Earnings Forecasts and Investment Recommendations", Contemporary Accounting Research 12, 131-160.

Florou, A. and P. Pope (2012), "Mandatory IFRS Adoption and Institutional Investment Decisions", The Accounting Review 87, 1993-2025.

Francis, J., K. Schipper and L. Vincent (2002), "Earnings Announcements and Competing Information", Journal of Accounting and Economics 33, 313-342.

Francis J. and L. Soffer (1997), "The Relative Informativeness of Analysts' Stock Recommendations and Earnings Forecast Revisions", Journal of Accounting and Research 35, 193-211. 
Frankel, R., S.P. Kothari and J. Weber (2006), "Determinants of the Informativeness of Analyst Research", Journal of Accounting and Economics 41, 29-54.

Gleason, C. A. and C. M. C. Lee (2003), “Analyst Forecast Revisions and Market Price Discovery", The Accounting Review 78, 193-225.

Graham, J., H. Campbell and S. Rajgopal (2005), "The Economic Implications of Corporate Financial Reporting”, Journal of Accounting and Economics 40, 3-73.

Hail, L. and C. Leuz (2007), "Capital Market Effects of Mandatory IFRS Reporting in the EU: Empirical Evidence”, Working paper.

Hong, H. and J. D. Kubik (2003), “Analyzing the Analysts: Career Concerns and Biased Earnings Forecasts”, The Journal of Finance 58, 313-351.

Hope, O-K. (2003), "Disclosure Practices, Enforcement of Accounting Standards, and Analysts' Forecast Accuracy: An International Study", Journal of Accounting Research 41, 235-272.

Horton, J., G. Serafeim and I. Serafeim (2013), “Does Mandatory IFRS Adoption Improve The Information Environment?”, Contemporary Accounting Research 30, $388-423$.

Howe, J. S., E. Unlu and X. M. Yan (2009), “The Predictive Content of Aggregate Analyst Recommendations", Journal of Accounting Research 47, 799-821.

Irani, A. J. and I. Karamanou (2003), "Regulation Fair Disclosure, analyst following, and analyst forecast dispersion", Accounting Horizons 17, 15-29.

Ivkovic, Z. and N. Jegadeesh (2004), "The Timing and Value of Forecast and Recommendation Revisions", Journal of Financial Economics 73, 433-463.

Jegadeesh N., J. Kim, S. Krische and C. Lee (2004), "Analyzing the Analysts: When Do Recommendations Add Value?", The Journal of Finance 59, 1083-1124.

Jegadeesh N. and W. Kim (2006), "Value of Analyst Recommendations: International Evidence", Journal of Financial Markets 9, 274-309.

Kadan, O., L. Madureira, R. Wang and T. Zach (2009), "Conflicts of Interest and Stock Recommendations: The Effects of the Global Settlement and Related Regulations", Review of Financial Studies 22, 4189-4217.

Kaufmann D., A. Kraay and M. Mastuzzi (2007), “Governance matters VI: Aggregate and Individual Governance Indicators 1996-2006”, Washington DC: The World Bank.

Kecskés, A., R. Michaely and K. L. Womack (2017), “Do Earnings Estimates Add Value to Sell-side Analysts' Investment Recommendations?", Management Science 63, 1855-1871. 
Kothari, S. P., S. Shu and P. D. Wysocki (2009), “Do Managers Withhold Bad News?”, Journal of Accounting Research 47, 241-276.

Lang, M. and R. Lundholm (1996), "Corporate Disclosure Policy and Analyst Behavior", The Accounting Review 71, 467-492.

Landsman, W., E. Maydew and J. Thornock (2012), “The Information Content of Annual Earnings Announcements and Mandatory Adoption of IFRS”, Journal of Accounting and Economics 53, 34-54.

Leuz, C., D. Nanda and P. Wysocki (2003), "Earnings Management and Investor Protection: an International Comparison", Journal of Financial Economics 69, 505-527.

Li, S. (2010), "Does Mandatory Adoption of International Financial Reporting Standards in the European Union Reduce the Cost of Equity Capital?", The Accounting Review $85,607-636$.

Loh, R. and R. Stulz (2011), “When are Analyst Recommendation Changes Influential?”, Review of Financial Studies 24, 593-627.

Malmendier, U. and D. Shanthikumar (2007), "Are Small Investors Naive about Incentives?”, Journal of Financial Economics 85, 457-489.

Mikhail, M., B. Walther and R. Wills (2007), "When Security Analysts Talk, Who Listens?”, The Accounting Review 82, 1227-1253.

Park, C. and E. Stice (2000), "Analyst Forecasting Ability and Stock Price Reaction to Forecast Revisions", Review of Accounting Studies 5, 259-272.

Preiato, J., Brown, P. and A. Tarca (2015), “A Comparison of Between-Country Measures of Legal Setting and Enforcement of Accounting Standards", Journal of Business Finance \& Accounting 42, 1-50.

Regulation (EC) No 1606/2002 of the European Parliament and of the Council of 19 July 2002 on the application of international accounting standards. http://eurlex.europa.eu/LexUriServ/LexUriServ.do?uri=OJ:L:2002:243:0001:0004:en:PDF

Securities and Exchange Commission. (2010), "Analyzing Analyst Recommendations". https://www.sec.gov/investor/pubs/analysts.htm

Soderstrom N. S. and K. J. Sun (2007), "IFRS Adoption and Accounting Quality: A Review", European Accounting Review 16, 675-702.

Stickel, S. (1995), "The Anatomy of the Performance of Buy and Sell Recommendations", Financial Analysts Journal Sept-Oct, 25-39. 
Tan, H., S. Wang and M. Welker (2011), "Analyst Following and Forecast Accuracy After Mandated IFRS Adoptions”, Journal of Accounting Research 49, 13071357.

Wang, X., D. Young and Z. Zhuan (2008), "The Effects of Mandatory Adoption of International Financial Reporting Standards on Information Environments", Working Paper, The Chinese University of Hong Kong.

Womack, L.K. (1996), “Do Brokerage Analysts' Recommendations Have Investment Value?", The Journal of Finance 51, 137-167.

Zhang, X. F. (2006), “Information Uncertainty and Analyst Forecast Behavior”, Contemporary Accounting Research 23, 565-590. 


\section{TABLE 1: Sample description}

Panel A presents the sample distribution separately for upgrades and downgrades. The pre- (post-) IFRS period relates to recommendations issued in or before (after) 2005. The mandatory sample consists of recommendations issued for firms that mandatorily adopted IFRS. The voluntary sample consists of recommendations issued for firms that had adopted IFRS before the EU mandated switch and are domiciled in countries with high legal enforcement. Panel B presents the country distribution for the mandatory sample and the study's main voluntary sample comprising firms from high enforcement. For comparison purposes the last two columns show the voluntary adopters from low enforcement countries that are only used in sensitivity tests.

Panel A: Sample distribution of upgrades and downgrades

\begin{tabular}{lccc} 
& All upgrades & Mandatory Sample & Voluntary Sample \\
\hline \multirow{2}{*}{ Pre-IFRS } & 2652 & 2251 & \\
& $52.50 \%$ & $54.50 \%$ & 401 \\
& & & $43.54 \%$ \\
Post-IFRS & 2399 & 1879 & 520 \\
& $47.50 \%$ & $45.50 \%$ & $56.46 \%$ \\
\hline Total upgrades & 5051 & 4130 & 921 \\
\hline
\end{tabular}

All Downgrades Mandatory Sample Voluntary Sample

\begin{tabular}{lccc} 
& All Downgrades & Mandatory Sample & Voluntary Sample \\
\hline \multirow{2}{*}{ Pre-IFRS } & 2756 & 2371 & \\
& $55.78 \%$ & $58.59 \%$ & 485 \\
& & & \\
Post-IFRS & 2185 & 1676 & 509 \\
& $44.22 \%$ & $41.41 \%$ & $56.94 \%$ \\
\hline Total downgrades & 4941 & 4047 & 894 \\
\hline \multicolumn{2}{l}{ Total number of } & & \\
Recommendations & 9992 & 8177 & 1815 \\
\hline
\end{tabular}




\begin{tabular}{|c|c|c|c|c|c|c|}
\hline \multirow[b]{2}{*}{ Country } & \multicolumn{2}{|c|}{ All recommendations } & \multicolumn{2}{|c|}{ Mandatory Sample } & \multicolumn{2}{|c|}{ Voluntary Sample } \\
\hline & Frequency & $\%$ & Frequency & $\%$ & Frequency & $\%$ \\
\hline Belgium & 323 & $3.23 \%$ & 184 & $2.25 \%$ & 139 & $7.66 \%$ \\
\hline Germany & 1938 & $19.40 \%$ & 871 & $10.65 \%$ & 1067 & $58.79 \%$ \\
\hline Denmark & 617 & $6.17 \%$ & 592 & $7.24 \%$ & 25 & $1.38 \%$ \\
\hline Spain & 193 & $1.93 \%$ & 193 & $2.36 \%$ & 0 & $0.00 \%$ \\
\hline Finland & 1514 & $15.15 \%$ & 1150 & $14.06 \%$ & 364 & $20.06 \%$ \\
\hline France & 1119 & $11.20 \%$ & 1099 & $13.44 \%$ & 20 & $1.10 \%$ \\
\hline UK & 1262 & $12.63 \%$ & 1262 & $15.43 \%$ & 0 & $0.00 \%$ \\
\hline Hungary & 6 & $0.06 \%$ & 0 & $0.00 \%$ & 6 & $0.33 \%$ \\
\hline Ireland & 1 & $0.01 \%$ & 1 & $0.01 \%$ & 0 & $0.00 \%$ \\
\hline Italy & 43 & $0.43 \%$ & 43 & $0.53 \%$ & 0 & $0.00 \%$ \\
\hline The Netherlands & 1404 & $14.05 \%$ & 1397 & $17.08 \%$ & 7 & $0.39 \%$ \\
\hline Poland & 62 & $0.62 \%$ & 36 & $0.44 \%$ & 26 & $1.43 \%$ \\
\hline Portugal & 132 & $1.32 \%$ & 81 & $0.99 \%$ & 51 & $2.81 \%$ \\
\hline Sweden & 1378 & $13.79 \%$ & 1268 & $15.51 \%$ & 110 & $6.06 \%$ \\
\hline Total & 9992 & $100.00 \%$ & 8177 & $100.00 \%$ & 1815 & $100.00 \%$ \\
\hline
\end{tabular}




\section{TABLE 2: Descriptive Statistics}

The table presents mean and median values of all independent variables across the full sample ( $n=9992)$. The first (second) line of each variable denotes the mandatory (voluntary) firms. The paired t-test and Wilcoxon rank sum tests are used to examine the statistical significance of the mean and median values, respectively. FOLL is the natural logarithm of analyst following. DISPERSION is calculated as the standard deviation of all annual earnings forecasts issued before the recommendation month. $A V G \_S U R P R I S E$ is the absolute value of the percentage difference between actual earnings and the most recent consensus earnings forecast. TOPBROKER takes the value 1 if the recommendation is issued by one of the top 10 brokerage firms, and 0 otherwise. EXPERIENCE is measured as the number of years in which the analyst issuing the recommendation revision has issued at least one earnings forecast for the firm. $R E C \_C D$ is the IBES level of recommendation ranging from 1 to 5 with 1 indicating a strong buy and 5 a strong sell. $S A M E \_E P S_{-} C H$ takes the value 1 if the recommendation announcement is made on the same day with an EPS forecast revision in the same direction. MOMENTUM is the compounded market adjusted return in a 90-day period before the recommendation. $M_{-} B$ is the ratio of market value to book value of equity. SIZE is the natural logarithm of total assets. ACCT_ENF takes the value of 1 for countries with high auditing and accounting setting enforcement and 0 otherwise, based on the sample median values of the measure in Brown et al. (2014). DIFF_ACCT takes the value 1 for firms domiciled in countries whose local GAAP is substantially different from IFRS, and 0 otherwise based on the sample median values from Bae et al. (2008). MC_GDP is the country's market capitalization deflated by GDP. Variable values on the first (second) line are based on the mandatory (voluntary) sample. Significance levels of $1 \%, 5 \%$ and $10 \%$ are indicated by ${ }^{\mathrm{a}},{ }^{\mathrm{b}}$ and ${ }^{\mathrm{c}}$ respectively.

Upgrades

\begin{tabular}{|c|c|c|c|c|c|c|}
\hline & \multicolumn{3}{|c|}{ Mean } & \multicolumn{3}{|c|}{ Median } \\
\hline & $\begin{array}{c}\text { Pre-IFRS } \\
\text { (1) }\end{array}$ & $\begin{array}{c}\text { Post-IFRS } \\
\text { (2) }\end{array}$ & $\begin{array}{l}\text { Difference } \\
(2)-(1)\end{array}$ & $\begin{array}{c}\text { Pre-IFRS } \\
\text { (1) }\end{array}$ & $\begin{array}{c}\text { Post-IFRS } \\
\text { (2) }\end{array}$ & $\begin{array}{l}\text { Difference } \\
(2)-(1)\end{array}$ \\
\hline \multirow[t]{2}{*}{ FOLL } & 2.6436 & 2.5789 & $-0.0647^{\mathrm{a}}$ & 2.7081 & 2.6391 & $-0.0690^{\mathrm{a}}$ \\
\hline & 2.6959 & 2.5728 & -0.1231 & 3.2189 & 2.9957 & $-0.2232^{\mathrm{a}}$ \\
\hline \multirow[t]{2}{*}{ DISPERSION } & 1.3344 & 0.9617 & $-0.3727^{b}$ & 0.2000 & 0.2200 & $0.0200^{\mathrm{a}}$ \\
\hline & 0.2231 & 0.9875 & $0.7644^{\mathrm{a}}$ & 0.1600 & 0.2200 & $0.0600^{\mathrm{a}}$ \\
\hline \multirow[t]{2}{*}{ AVG_SURPRISE } & 0.5982 & 0.1894 & $-0.4088^{\mathrm{a}}$ & 0.1168 & 0.0609 & $-0.0559^{\mathrm{a}}$ \\
\hline & 0.2837 & 0.2033 & -0.0804 & 0.0812 & 0.0820 & 0.0008 \\
\hline \multirow[t]{2}{*}{ TOPBROKER } & 0.2621 & 0.2390 & $-0.0231^{\mathrm{c}}$ & 0 & 0 & $0^{\mathrm{c}}$ \\
\hline & 0.2319 & 0.1788 & $-0.0531^{\mathrm{b}}$ & 0 & 0 & $0^{\mathrm{b}}$ \\
\hline \multirow[t]{2}{*}{ EXPERIENCE } & 2.9738 & 3.6557 & $0.6819^{a}$ & 3 & 3 & $0^{\mathrm{a}}$ \\
\hline & 3.5611 & 4.3173 & $0.7562^{\mathrm{a}}$ & 3 & 4 & $1^{\mathrm{a}}$ \\
\hline \multirow[t]{2}{*}{$R E C \_C D$} & 1.9698 & 1.8930 & $-0.0768^{\mathrm{a}}$ & 2 & 2 & $0^{\mathrm{a}}$ \\
\hline & 1.9227 & 1.8346 & $-0.0881^{c}$ & 2 & 2 & $0^{\mathrm{b}}$ \\
\hline \multirow[t]{2}{*}{$S A M E \_E P S \_C H$} & 0.3607 & 0.4045 & $0.0438^{\mathrm{a}}$ & 0 & 0 & $0^{\mathrm{a}}$ \\
\hline & 0.3067 & 0.3423 & 0.0356 & 0 & 0 & 0 \\
\hline \multirow[t]{2}{*}{ MOMENTUM } & 0.0064 & -0.0171 & $-0.0235^{\mathrm{a}}$ & 0.0020 & -0.0105 & $-0.0125^{\mathrm{a}}$ \\
\hline & -0.0169 & -0.0512 & $-0.0343^{\mathrm{a}}$ & -0.0047 & -0.0298 & $-0.0251^{\mathrm{a}}$ \\
\hline \multirow[t]{2}{*}{$M \_B$} & 3.1732 & 3.6187 & $0.4455^{\mathrm{a}}$ & 2.2403 & 2.3830 & $0.1427^{\mathrm{a}}$ \\
\hline & 2.4421 & 2.6046 & $0.1625^{\mathrm{c}}$ & 2.1448 & 2.3166 & 0.1718 \\
\hline \multirow[t]{2}{*}{ SIZE } & 8.0060 & 7.9854 & -0.0206 & 7.9443 & 7.8801 & -0.0642 \\
\hline & 8.6822 & 8.6276 & -0.0546 & 8.6570 & 8.9780 & 0.3210 \\
\hline \multirow[t]{2}{*}{$A C C T \_E N F$} & 0.6219 & 0.4231 & $-0.1988^{\mathrm{a}}$ & 1 & 1 & $0^{\mathrm{a}}$ \\
\hline & 0.8105 & 0.6750 & $-0.1355^{\mathrm{a}}$ & 1 & 1 & 0 \\
\hline$D I F F \_A C C T$ & 0.5087 & 0.5375 & $0.0288^{\mathrm{c}}$ & 1 & 1 & $0^{\mathrm{c}}$ \\
\hline
\end{tabular}




\begin{tabular}{lrrrrrr} 
& 0.9352 & 0.9327 & -0.0025 & 1 & 1 & 0 \\
$M C \_G D P$ & 88.8307 & 117.6057 & $28.7750^{\mathrm{a}}$ & 90.7739 & 122.2220 & $31.4481^{\mathrm{a}}$ \\
& 59.6381 & 84.9939 & $25.3558^{\mathrm{a}}$ & 43.7977 & 63.2446 & $19.4469^{\mathrm{a}}$ \\
\hline
\end{tabular}

Downgrades

\begin{tabular}{|c|c|c|c|c|c|c|}
\hline & \multicolumn{3}{|c|}{ Mean } & \multicolumn{3}{|c|}{ Median } \\
\hline & $\begin{array}{c}\text { Pre-IFRS } \\
\text { (1) }\end{array}$ & $\begin{array}{c}\text { Post-IFRS } \\
\text { (2) }\end{array}$ & $\begin{array}{c}\text { Difference } \\
(2)-(1)\end{array}$ & $\begin{array}{c}\text { Pre-IFRS } \\
\text { (1) }\end{array}$ & $\begin{array}{c}\text { Post-IFRS } \\
\text { (2) }\end{array}$ & $\begin{array}{c}\text { Difference } \\
(2)-(1)\end{array}$ \\
\hline \multirow[t]{2}{*}{ FOLL } & 2.6122 & 2.5712 & $-0.0410^{c}$ & 2.7081 & 2.6391 & $-0.0690^{\mathrm{b}}$ \\
\hline & 2.6481 & 2.6435 & -0.0046 & 3.1781 & 2.9957 & -0.1824 \\
\hline \multirow[t]{2}{*}{ DISPERSION } & 1.1595 & 1.0234 & -0.1361 & 0.1800 & 0.2300 & $0.0500^{\mathrm{a}}$ \\
\hline & 0.2506 & 0.9365 & $0.6859^{\mathrm{a}}$ & 0.1700 & 0.2100 & $0.0400^{\mathrm{b}}$ \\
\hline \multirow[t]{2}{*}{ AVG_SURPRISE } & 0.7771 & 0.2204 & $-0.5567^{\mathrm{a}}$ & 0.1178 & 0.0666 & $-0.0512^{\mathrm{a}}$ \\
\hline & 0.3297 & 0.2182 & -0.1115 & 0.0864 & 0.0879 & 0.0015 \\
\hline \multirow[t]{2}{*}{ TOPBROKER } & 0.2644 & 0.2208 & $-0.0436^{\mathrm{a}}$ & 0 & 0 & $0^{\mathrm{a}}$ \\
\hline & 0.2286 & 0.1788 & $-0.0498^{c}$ & 0 & 0 & $0^{c}$ \\
\hline \multirow[t]{2}{*}{ EXPERIENCE } & 2.9561 & 3.6211 & $0.6650^{\mathrm{a}}$ & 3 & 3 & $0^{\mathrm{a}}$ \\
\hline & 3.4234 & 4.2692 & $0.8458^{\mathrm{a}}$ & 3 & 4 & $1^{\mathrm{a}}$ \\
\hline \multirow[t]{2}{*}{$R E C \_C D$} & 3.4369 & 3.3634 & $-0.0735^{\mathrm{a}}$ & 3 & 3 & $0^{\mathrm{a}}$ \\
\hline & 3.3818 & 3.4361 & 0.0543 & 3 & 3 & 0 \\
\hline \multirow[t]{2}{*}{ SAME_EPS_CH } & 0.3496 & 0.2942 & $-0.0554^{\mathrm{a}}$ & 0 & 0 & $0^{\mathrm{a}}$ \\
\hline & 0.3506 & 0.2947 & $-0.0559^{c}$ & 0 & 0 & $0^{c}$ \\
\hline \multirow[t]{2}{*}{ MOMENTUM } & 0.0092 & 0.0134 & 0.0042 & 0.0088 & 0.0105 & 0.0017 \\
\hline & -0.0137 & -0.0151 & -0.0288 & 0 & -0.0026 & -0.0026 \\
\hline \multirow[t]{2}{*}{$M \_B$} & 3.0967 & 3.5102 & $0.4135^{\mathrm{a}}$ & 2.2403 & 2.4542 & $0.2139^{\mathrm{a}}$ \\
\hline & 2.3816 & 2.5728 & $0.1912^{b}$ & 2.1448 & 2.2088 & 0.0640 \\
\hline \multirow[t]{2}{*}{ SIZE } & 7.8712 & 7.9210 & 0.0498 & 7.8646 & 7.8047 & -0.0599 \\
\hline & 8.4898 & 8.7199 & $0.2301^{\mathrm{c}}$ & 8.3956 & 8.9780 & $0.5824^{\mathrm{b}}$ \\
\hline \multirow[t]{2}{*}{$A C C T \_E N F$} & 0.4585 & 0.7333 & $0.2748^{\mathrm{a}}$ & 0 & 1 & $1^{\mathrm{a}}$ \\
\hline & 0.1610 & 0.3399 & $0.1789^{\mathrm{a}}$ & 0 & 0 & $0^{\mathrm{a}}$ \\
\hline \multirow[t]{2}{*}{$D I F F \_A C C T$} & 0.5032 & 0.5376 & $0.0344^{\mathrm{b}}$ & 1 & 1 & $0^{\mathrm{b}}$ \\
\hline & 0.9377 & 0.9371 & -0.0006 & 1 & 1 & 0 \\
\hline \multirow[t]{2}{*}{$M C \_G D P$} & 90.1965 & 118.2276 & $28.0311^{\mathrm{a}}$ & 90.7739 & 124.8385 & $34.0646^{\mathrm{a}}$ \\
\hline & 58.9990 & 88.3650 & $29.3660^{\mathrm{a}}$ & 43.7977 & 63.2446 & $19.4469^{a}$ \\
\hline
\end{tabular}


Table 3: Mean and Median Differences in Market Reaction

This table presents the mean and median differences in CAR between the mandatory and voluntary samples and between the pre- and post-IFRS periods. The number of observations for each sub-sample is shown in table 1 . $C A R$ is cumulative risk adjusted abnormal returns over the three day window around the recommendation announcement. The pre- (post-) IFRS period relates to recommendations issued in or before (after) 2005. Significance levels of $1 \%, 5 \%$ and $10 \%$ are indicated by ${ }^{a},{ }^{b}$ and ${ }^{c}$ respectively.

\begin{tabular}{|c|c|c|c|}
\hline & \multicolumn{3}{|c|}{ Upgrades } \\
\hline & \multirow{3}{*}{$\begin{array}{c}\text { Pre-IFRS } \\
\text { (1) }\end{array}$} & & \multirow{3}{*}{$\begin{array}{l}\text { Difference betweer } \\
\text { Pre and Post } \\
(2)-(1)\end{array}$} \\
\hline & & Post-IFRS & \\
\hline & & (2) & \\
\hline Mandatory Mean & $0.00551^{\mathrm{a}}$ & $0.01415^{\mathrm{a}}$ & $0.00864^{\mathrm{a}}$ \\
\hline Voluntary Mean & $0.00913^{\mathrm{a}}$ & $0.00950^{\mathrm{a}}$ & 0.00037 \\
\hline Voluntary-Mandatory & $0.00362^{\mathrm{b}}$ & $-0.00465^{\mathrm{b}}$ & \\
\hline Mandatory Median & $0.00346^{\mathrm{a}}$ & $0.00973^{\mathrm{a}}$ & $0.00627^{\mathrm{a}}$ \\
\hline Voluntary Median & $0.00783^{\mathrm{a}}$ & $0.00678^{\mathrm{a}}$ & -0.00105 \\
\hline Voluntary-Mandatory & $0.00437^{\mathrm{a}}$ & -0.00295 & \\
\hline
\end{tabular}

\begin{tabular}{lccc} 
& \multicolumn{3}{c}{ Downgrades } \\
\cline { 2 - 4 } & & & Difference between \\
& Pre-IFRS & Post-IFRS & $(2)-(1)$ \\
\cline { 2 - 4 } Mandatory Mean & $(1)$ & $(2)$ & $-0.00888^{\mathrm{a}}$ \\
Voluntary Mean & $-0.00630^{\mathrm{a}}$ & $-0.01518^{\mathrm{a}}$ & 0.00371 \\
Voluntary-Mandatory & $-0.01525^{\mathrm{a}}$ & $-0.01154^{\mathrm{a}}$ & \\
& $-0.00895^{\mathrm{a}}$ & 0.00364 & \\
Mandatory Median & $-0.00446^{\mathrm{a}}$ & $-0.01077^{\mathrm{a}}$ & $-0.00631^{\mathrm{a}}$ \\
Voluntary Median & $-0.01214^{\mathrm{a}}$ & $-0.00829^{\mathrm{a}}$ & $0.00385^{\mathrm{c}}$ \\
Voluntary-Mandatory & $-0.00768^{\mathrm{a}}$ & 0.00248 & \\
\hline
\end{tabular}


Table 4: The impact of increased disclosure on the informativeness of recommendation changes

The dependent variable $C A R$ is cumulative risk adjusted abnormal returns over the three day window around the recommendation announcement. POST2005 takes the value 1 when the recommendation announcement is issued in the post-IFRS period and 0 otherwise. MAND takes the value 1 when the recommendation is issued for mandatory adopters and 0 for the control sample of voluntary adopters. FOLL is the natural logarithm of analyst following. DISPERSION is calculated as the standard deviation of all annual earnings forecasts issued before the recommendation month. AVG_SURPRISE is the absolute value of the percentage difference between actual earnings and the most recent consensus earnings forecast. TOPBROKER takes the value 1 if the recommendation is issued by one of the top 10 brokerage firms, and 0 otherwise. EXPERIENCE is measured as the number of years in which the analyst issuing the recommendation revision has issued at least one earnings forecast for the firm. $R E C_{-} C D$ is the IBES level of recommendation ranging from 1 to 5 with 1 indicating a strong buy and 5 a strong sell. SAME_EPS_CH takes the value 1 if the recommendation announcement is made on the same day with an EPS forecast revision in the same direction. MOMENTUM is the compounded market adjusted return in a 90-day period before the recommendation. $M_{-} B$ is the ratio of market value to book value of equity. SIZE is the natural logarithm of total assets. $A C C T_{-} E N F$ takes the value of 1 for countries with high auditing and accounting setting enforcement and 0 otherwise, based on the sample median values of the measure in Brown et al. (2014).DIFF_ACCT takes the value 1 for firms domiciled in countries whose local GAAP is substantially different from IFRS, and 0 otherwise based on the sample median values from Bae et al. (2008). MC_GDP is the country's market capitalization deflated by GDP. Errors are clustered by recommendation date. Second row shows p-values. Significance levels of $1 \%, 5 \%$ and $10 \%$ are indicated by ${ }^{\mathrm{a}},{ }^{\mathrm{b}}$ and ${ }^{\mathrm{c}}$ respectively.

\begin{tabular}{|c|c|c|}
\hline Panel A: Upgrades & (1) & (2) \\
\hline POST2005 & -0.00090 & -0.00155 \\
\hline & 0.73 & 0.57 \\
\hline MAND & $\begin{array}{c}-0.00365^{\mathrm{c}} \\
0.09\end{array}$ & $\begin{array}{c}-0.00418^{\mathrm{b}} \\
0.03\end{array}$ \\
\hline POST2005*MAND & $\begin{array}{c}0.00839^{\mathrm{a}} \\
0.01\end{array}$ & $\begin{array}{c}0.00860^{\mathrm{a}} \\
0.01\end{array}$ \\
\hline FOLL & $\begin{array}{c}-0.00292^{\mathrm{b}} \\
0.02\end{array}$ & $\begin{array}{c}-0.00224^{\mathrm{a}} \\
0.01\end{array}$ \\
\hline DISPERSION & $\begin{array}{c}0.00013 \\
0.14\end{array}$ & $\begin{array}{c}0.00012 \\
0.14\end{array}$ \\
\hline$A V G \_S U R P R I S E$ & $\begin{array}{c}-0.00002 \\
0.81\end{array}$ & $\begin{array}{c}-0.00001 \\
0.92\end{array}$ \\
\hline TOPBROKER & $\begin{array}{c}0.00651^{\mathrm{a}} \\
0.01\end{array}$ & $\begin{array}{c}0.00625^{\mathrm{a}} \\
0.01\end{array}$ \\
\hline EXPERIENCE & $\begin{array}{c}0.00050^{\mathrm{c}} \\
0.06\end{array}$ & $\begin{array}{c}0.00051^{\mathrm{c}} \\
0.06\end{array}$ \\
\hline$R E C \_C D$ & $\begin{array}{c}-0.00178^{\mathrm{a}} \\
0.01\end{array}$ & $\begin{array}{c}-0.00183^{\mathrm{a}} \\
0.01\end{array}$ \\
\hline$S A M E \_E P S \_C H$ & $\begin{array}{c}0.00565^{\mathrm{a}} \\
0.01\end{array}$ & $\begin{array}{c}0.00554^{\mathrm{a}} \\
0.01\end{array}$ \\
\hline MOMENTUM & $\begin{array}{c}-0.00799^{\mathrm{b}} \\
0.05\end{array}$ & $\begin{array}{c}-0.00858^{\mathrm{b}} \\
0.03\end{array}$ \\
\hline$M \_B$ & $\begin{array}{c}0.00064^{\mathrm{a}} \\
0.01\end{array}$ & $\begin{array}{c}0.00061^{\mathrm{a}} \\
0.01\end{array}$ \\
\hline
\end{tabular}




\begin{tabular}{lcc} 
SIZE & -0.00015 & 0.00002 \\
ACCT_ENF & 0.76 & 0.96 \\
& & $0.00369^{\mathrm{b}}$ \\
DIFF_ACCT & & 0.02 \\
& & 0.00211 \\
$M C \_G D P$ & & 0.26 \\
& & 0.00003 \\
& & 0.34 \\
Country Effects & & \\
Industry effects & YES & NO \\
& YES & YES \\
N & & \\
Adj. R-Sq & 5051 & 5051 \\
\hline
\end{tabular}




\begin{tabular}{|c|c|c|}
\hline Panel B: Downgrades & (1) & (2) \\
\hline POST2005 & $\begin{array}{c}0.00277 \\
0.33\end{array}$ & $\begin{array}{c}0.00292 \\
0.33\end{array}$ \\
\hline$M A N D$ & $\begin{array}{c}0.00990^{\mathrm{a}} \\
0.01\end{array}$ & $\begin{array}{c}0.01008^{\mathrm{a}} \\
0.01\end{array}$ \\
\hline POST2005*MAND & $\begin{array}{c}-0.01283^{\mathrm{a}} \\
0.01\end{array}$ & $\begin{array}{c}-0.01255^{\mathrm{a}} \\
0.01\end{array}$ \\
\hline$F O L L$ & $\begin{array}{c}-0.00336^{\mathrm{a}} \\
0.01\end{array}$ & $\begin{array}{c}-0.00115 \\
0.20\end{array}$ \\
\hline DISPERSION & $\begin{array}{c}0.00006 \\
0.56\end{array}$ & $\begin{array}{c}0.00013 \\
0.16\end{array}$ \\
\hline$A V G \_S U R P R I S E$ & $\begin{array}{c}-0.00021 \\
0.18\end{array}$ & $\begin{array}{c}-0.00019 \\
0.21\end{array}$ \\
\hline TOPBROKER & $\begin{array}{c}-0.00230^{\mathrm{c}} \\
0.10\end{array}$ & $\begin{array}{c}-0.00201 \\
0.14\end{array}$ \\
\hline EXPERIENCE & $\begin{array}{c}-0.00072^{\mathrm{a}} \\
0.01\end{array}$ & $\begin{array}{c}-0.00059^{\mathrm{b}} \\
0.04\end{array}$ \\
\hline$R E C \_C D$ & $\begin{array}{c}-0.00055 \\
0.40\end{array}$ & $\begin{array}{c}-0.00083 \\
0.20\end{array}$ \\
\hline$S A M E \_E P S \_C H$ & $\begin{array}{c}-0.00859^{\mathrm{a}} \\
0.01\end{array}$ & $\begin{array}{c}-0.00866^{\mathrm{a}} \\
0.01\end{array}$ \\
\hline MOMENTUM & $\begin{array}{c}0.01368^{\mathrm{a}} \\
0.01\end{array}$ & $\begin{array}{c}0.01478^{\mathrm{a}} \\
0.01\end{array}$ \\
\hline$M \_B$ & $\begin{array}{c}0.00120^{\mathrm{a}} \\
0.01\end{array}$ & $\begin{array}{c}0.00100^{\mathrm{a}} \\
0.01\end{array}$ \\
\hline SIZE & $\begin{array}{c}0.00322^{\mathrm{a}} \\
0.01\end{array}$ & $\begin{array}{c}0.00210^{\mathrm{a}} \\
0.01\end{array}$ \\
\hline$A C C T \_E N F$ & & $\begin{array}{c}-0.00536^{\mathrm{a}} \\
0.01\end{array}$ \\
\hline$D I F F \_A C C T$ & & $\begin{array}{c}0.00170 \\
0.37\end{array}$ \\
\hline$M C \_G D P$ & & $\begin{array}{c}0.00004 \\
0.19\end{array}$ \\
\hline $\begin{array}{l}\text { Country Effects } \\
\text { Industry effects }\end{array}$ & $\begin{array}{l}\text { YES } \\
\text { YES }\end{array}$ & $\begin{array}{l}\text { NO } \\
\text { YES }\end{array}$ \\
\hline $\mathrm{N}$ & 4941 & 4941 \\
\hline Adj. R-Sq & 0.1180 & 0.0508 \\
\hline
\end{tabular}




\begin{tabular}{|c|c|c|c|c|c|c|}
\hline & \multicolumn{3}{|c|}{ Upgrades } & \multicolumn{3}{|c|}{ Downgrades } \\
\hline & Mandatory & Voluntary & Difference & Mandatory & Voluntary & Difference \\
\hline \multirow[t]{2}{*}{ POST2005 } & $0.00727^{\mathrm{a}}$ & -0.00330 & $0.01057^{\mathrm{a}}$ & $-0.01007^{a}$ & 0.00304 & $-0.01311^{\mathrm{a}}$ \\
\hline & 0.01 & 0.21 & 0.01 & 0.01 & 0.31 & 0.01 \\
\hline \multirow[t]{2}{*}{ FOLL } & $-0.00408^{\mathrm{a}}$ & $-0.01035^{\mathrm{c}}$ & 0.00627 & $-0.00545^{\mathrm{a}}$ & 0.00482 & -0.01027 \\
\hline & 0.01 & 0.06 & 0.28 & 0.01 & 0.48 & 0.14 \\
\hline \multirow[t]{2}{*}{ DISPERSION } & 0.00008 & $0.00601^{\mathrm{a}}$ & $-0.00593^{\mathrm{a}}$ & 0.00062 & 0.00092 & -0.00085 \\
\hline & 0.37 & 0.01 & 0.01 & 0.55 & 0.79 & 0.81 \\
\hline \multirow[t]{2}{*}{ AVG_SURPRISE } & 0.00002 & $-0.00355^{\mathrm{a}}$ & $0.00357^{\mathrm{a}}$ & -0.00022 & -0.00027 & 0.00005 \\
\hline & 0.79 & 0.01 & 0.01 & 0.15 & 0.89 & 0.98 \\
\hline \multirow[t]{2}{*}{ TOPBROKER } & $0.00597^{\mathrm{a}}$ & $0.01014^{\mathrm{a}}$ & -0.00417 & -0.00131 & $-0.00585^{\mathrm{c}}$ & 0.00454 \\
\hline & 0.01 & 0.01 & 0.21 & 0.37 & 0.09 & 0.21 \\
\hline \multirow[t]{2}{*}{ EXPERIENCE } & $0.00057^{\mathrm{c}}$ & 0.00065 & -0.00008 & $-0.00079^{\mathrm{a}}$ & -0.00055 & -0.00025 \\
\hline & 0.06 & 0.26 & 0.90 & 0.01 & 0.38 & 0.72 \\
\hline \multirow[t]{2}{*}{$R E C \_C D$} & $-0.00188^{\mathrm{a}}$ & -0.00085 & -0.00103 & 0.00073 & $-0.00586^{\mathrm{a}}$ & $0.00659^{\mathrm{a}}$ \\
\hline & 0.01 & 0.62 & 0.58 & 0.30 & 0.01 & 0.01 \\
\hline \multirow[t]{2}{*}{$S A M E \_E P S \_C H$} & $0.00484^{\mathrm{a}}$ & $0.00946^{\mathrm{a}}$ & -0.00462 & $-0.00886^{\mathrm{a}}$ & $-0.00718^{b}$ & -0.00168 \\
\hline & 0.01 & 0.01 & 0.13 & 0.01 & 0.02 & 0.60 \\
\hline \multirow[t]{2}{*}{ MOMENTUM } & $-0.01224^{\mathrm{a}}$ & 0.01234 & $-0.02458^{\mathrm{b}}$ & $0.00956^{\mathrm{c}}$ & $0.03267^{\mathrm{a}}$ & $-0.02311^{\mathrm{c}}$ \\
\hline & 0.01 & 0.23 & 0.03 & 0.10 & 0.01 & 0.07 \\
\hline \multirow[t]{2}{*}{$M \_B$} & $0.00062^{\mathrm{a}}$ & 0.00182 & -0.00120 & $0.00118^{\mathrm{a}}$ & 0.00102 & 0.00017 \\
\hline & 0.01 & 0.14 & 0.33 & 0.01 & 0.47 & 0.91 \\
\hline \multirow[t]{2}{*}{ SIZE } & 0.00010 & 0.00146 & -0.00136 & $0.00356^{\mathrm{a}}$ & 0.00277 & 0.00079 \\
\hline & 0.86 & 0.40 & 0.46 & 0.01 & 0.19 & 0.70 \\
\hline Country Effects & YES & YES & & YES & YES & \\
\hline Industry effects & YES & YES & & YES & YES & \\
\hline $\mathrm{N}$ & 4130 & 921 & & 4047 & 894 & \\
\hline Adj. R-Sq & 0.1076 & 0.1347 & & 0.1137 & 0.1748 & \\
\hline
\end{tabular}




\section{Table 5: The impact of IFRS and enforcement on the informativeness of recommendation changes}

The dependent variable $C A R$ is cumulative risk adjusted abnormal returns over the three day window around the recommendation announcement. POST2005 takes the value 1 when the recommendation announcement is issued in post-IFRS period 0 otherwise. MAND takes the value 1 when the recommendation is issued for mandatory adopters and 0 for the control sample of voluntary adopters. FOLL is the natural logarithm of analyst following. DISPERSION is calculated as the standard deviation of all annual earnings forecasts issued before the recommendation month. AVG_SURPRISE is the absolute value of the percentage difference between actual earnings and the most recent consensus earnings forecast. TOPBROKER takes the value 1 if the recommendation is issued by one of the top 10 brokerage firms, and 0 otherwise. EXPERIENCE is measured as the number of years in which the analyst issuing the recommendation revision has issued at least one earnings forecast for the firm. $R E C_{-} C D$ is the IBES level of recommendation ranging from 1 to 5 with 1 indicating a strong buy and 5 a strong sell. SAME_EPS_CH takes the value 1 if the recommendation announcement is made on the same day with an EPS forecast revision in the same direction. MOMENTUM is the compounded market adjusted return in a 90-day period before the recommendation. $M_{-} B$ is the ratio of market value to book value of equity. SIZE is the natural logarithm of total assets. $A C C T_{-} E N F$ takes the value of 1 for countries with high auditing and accounting setting enforcement and 0 otherwise, based on the sample median values of the measure in Brown et al. (2014). DIFF_ACCT takes the value 1 for firms domiciled in countries whose local GAAP is substantially different from IFRS, and 0 otherwise based on the sample median values from Bae et al. (2008). MC_GDP is the country's market capitalization deflated by GDP. Errors are clustered by recommendation date. Second row shows p-values. Significance levels of $1 \%, 5 \%$ and $10 \%$ are indicated by ${ }^{\mathrm{a}},{ }^{\mathrm{b}}$ and ${ }^{\mathrm{c}}$ respectively.

\begin{tabular}{lcc} 
& Upgrades & Downgrades \\
\hline POST2005 & 0.00129 & $-0.00475^{\mathrm{b}}$ \\
POST2005*ACCT_ENF & 0.51 & 0.05 \\
& $0.01010^{\mathrm{a}}$ & $-0.00794^{\mathrm{a}}$ \\
FOLL & 0.01 & 0.01 \\
& $-0.00437^{\mathrm{a}}$ & -0.00160 \\
DISPERSION & 0.01 & 0.21 \\
& 0.00004 & 0.00006 \\
AVG_SURPRISE & 0.60 & 0.56 \\
TOPBROKER & -0.00001 & -0.00019 \\
& 0.88 & 0.21 \\
EXPERIENCE & $0.00574^{\mathrm{a}}$ & -0.00111 \\
& 0.01 & 0.45 \\
REC_CD & $0.00054^{\mathrm{c}}$ & $-0.00068^{\mathrm{b}}$ \\
SAME_EPS_CH & 0.07 & 0.03 \\
MOMENTUM & $-0.00179^{\mathrm{a}}$ & 0.00046 \\
M_B & 0.01 & 0.51 \\
SIZE & $0.00469^{\mathrm{a}}$ & $-0.00893^{\mathrm{a}}$ \\
ACCT_ENF & 0.01 & 0.01 \\
DIFF_ACCT & $-0.01266^{\mathrm{a}}$ & $0.01074^{\mathrm{c}}$ \\
& 0.01 & 0.07 \\
& $0.00059^{\mathrm{a}}$ & $0.00092^{\mathrm{a}}$ \\
& 0.01 & 0.01 \\
& 0.00038 & $0.00193^{\mathrm{a}}$ \\
& 0.39 & 0.01 \\
& -0.00235 & $-0.00278^{\mathrm{c}}$ \\
& 0.15 & 0.09 \\
& 0.00219 & 0.00181 \\
& 0.28 & 0.40 \\
& &
\end{tabular}


$M C \_G D P$

0.00003

0.39

0.00006

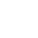

Country effects

Industry effects

NO

YES

NO

YES

$\mathrm{N}$

4130

4047

Adj. R-Sq

0.1108

0.1073 
Table 6: The informativeness of recommendation changes around earnings announcements The dependent variable $C A R$ is cumulative risk adjusted abnormal returns over the three day window around recommendation announcements issued in a period of 30 days after corporate earnings announcements (post-EAD) compared to the period away from earnings announcements (no-EAD). POST2005 takes the value 1 when the recommendation announcement is issued in post-IFRS period and 0 otherwise. MAND takes the value 1 when the recommendation is issued for mandatory adopters and 0 for the control sample of voluntary adopters. FOLL is the natural logarithm of analyst following. DISPERSION is calculated as the standard deviation of all annual earnings forecasts issued before the recommendation month. AVG_SURPRISE is the absolute value of the percentage difference between actual earnings and the most recent consensus earnings forecast. TOPBROKER takes the value 1 if the recommendation is issued by one of the top 10 brokerage firms, and 0 otherwise. EXPERIENCE is measured as the number of years in which the analyst issuing the recommendation revision has issued at least one earnings forecast for the firm. $R E C \_C D$ is the IBES level of recommendation ranging from 1 to 5 with 1 indicating a strong buy and 5 a strong sell. SAME_EPS_CH takes the value 1 if the recommendation announcement is made on the same day with an EPS forecast revision in the same direction. MOMENTUM is the compounded market adjusted return in a 90-day period before the recommendation. $M_{-} B$ is the ratio of market value to book value of equity. SIZE is the natural logarithm of total assets. Errors are clustered by recommendation date. Second row shows p-values. Significance levels of $1 \%, 5 \%$ and $10 \%$ are indicated by ${ }^{\mathrm{a}},{ }^{\mathrm{b}}$ and ${ }^{\mathrm{c}}$ respectively.

\begin{tabular}{|c|c|c|c|c|c|c|}
\hline & \multicolumn{2}{|c|}{ Upgrades } & \multicolumn{4}{|c|}{ Downgrades } \\
\hline & POST-EAD & NO-EAD & Difference & POST-EAD & NO-EAD & Difference \\
\hline \multirow[t]{2}{*}{ POST2005 } & -0.00652 & 0.00097 & -0.00749 & 0.00655 & 0.00229 & 0.00426 \\
\hline & 0.23 & 0.73 & 0.21 & 0.12 & 0.33 & 0.37 \\
\hline \multirow[t]{2}{*}{$M A N D$} & $-0.01042^{\mathrm{b}}$ & -0.00112 & -0.00929 & $0.00785^{\mathrm{c}}$ & 0.00349 & 0.00435 \\
\hline & 0.05 & 0.62 & 0.11 & 0.09 & 0.12 & 0.39 \\
\hline \multirow[t]{2}{*}{ POST2005*MAND } & $0.01699^{\mathrm{a}}$ & $0.00559^{c}$ & $0.01140^{\mathrm{c}}$ & $-0.01967^{\mathrm{a}}$ & $-0.00969^{a}$ & $-0.00998^{c}$ \\
\hline & 0.01 & 0.07 & 0.09 & 0.01 & 0.01 & 0.07 \\
\hline \multirow[t]{2}{*}{ FOLL } & -0.00196 & -0.00180 & -0.00016 & $-0.00637^{\mathrm{c}}$ & -0.00109 & -0.00528 \\
\hline & 0.54 & 0.15 & 0.96 & 0.09 & 0.38 & 0.18 \\
\hline \multirow[t]{2}{*}{ DISPERSION } & -0.00008 & 0.00016 & -0.00024 & -0.00026 & 0.00011 & -0.00037 \\
\hline & 0.71 & 0.12 & 0.32 & 0.23 & 0.29 & 0.12 \\
\hline \multirow[t]{2}{*}{ AVG_SURPRISE } & 0.00020 & -0.00007 & 0.00027 & -0.00003 & -0.00019 & 0.00016 \\
\hline & 0.25 & 0.50 & 0.18 & 0.91 & 0.19 & 0.56 \\
\hline \multirow[t]{2}{*}{ TOPBROKER } & $0.00793^{\mathrm{b}}$ & $0.00680^{\mathrm{a}}$ & 0.00113 & 0.00181 & -0.00203 & 0.00384 \\
\hline & 0.02 & 0.01 & 0.76 & 0.65 & 0.11 & 0.35 \\
\hline \multirow[t]{2}{*}{ EXPERIENCE } & $0.00113^{\mathrm{c}}$ & $0.00048^{c}$ & 0.00064 & -0.00048 & $-0.00053^{c}$ & 0.00004 \\
\hline & 0.08 & 0.10 & 0.35 & 0.45 & 0.07 & 0.95 \\
\hline \multirow{2}{*}{$R E C \_C D$} & -0.00128 & $-0.00171^{\mathrm{a}}$ & 0.00044 & 0.00009 & -0.00099 & 0.00108 \\
\hline & 0.52 & 0.01 & 0.83 & 0.95 & 0.14 & 0.53 \\
\hline \multirow[t]{2}{*}{$S A M E \_E P S \_C H$} & $0.01151^{\mathrm{a}}$ & $0.00429^{\mathrm{a}}$ & $0.00722^{\mathrm{b}}$ & $-0.01305^{\mathrm{a}}$ & $-0.00634^{\mathrm{a}}$ & $-0.00671^{\mathrm{b}}$ \\
\hline & 0.01 & 0.01 & 0.03 & 0.01 & 0.01 & 0.05 \\
\hline \multirow[t]{2}{*}{ MOMENTUM } & -0.00824 & -0.00629 & -0.00194 & $0.02743^{\mathrm{b}}$ & 0.00273 & $0.02470^{\mathrm{c}}$ \\
\hline & 0.39 & 0.15 & 0.85 & 0.05 & 0.56 & 0.08 \\
\hline \multirow[t]{2}{*}{$M \_B$} & 0.00073 & $0.00052^{\mathrm{b}}$ & 0.00021 & $0.00127^{\mathrm{b}}$ & $0.00113^{\mathrm{a}}$ & 0.00014 \\
\hline & 0.12 & 0.02 & 0.67 & 0.02 & 0.01 & 0.81 \\
\hline \multirow[t]{2}{*}{ SIZE } & -0.00009 & -0.00035 & 0.00026 & $0.00421^{\mathrm{a}}$ & $0.00233^{\mathrm{a}}$ & 0.00188 \\
\hline & 0.94 & 0.49 & 0.86 & 0.01 & 0.01 & 0.25 \\
\hline Country Effects & YES & YES & & YES & YES & \\
\hline Industry effects & YES & YES & & YES & YES & \\
\hline $\mathrm{N}$ & 952 & 4453 & & 936 & 4305 & \\
\hline Adj. R-Sq & 0.1633 & 0.0884 & & 0.2090 & 0.0869 & \\
\hline
\end{tabular}




\section{Table 7: US control sample}

The dependent variable $C A R$ is cumulative risk adjusted abnormal returns over the three day window around the recommendation announcement. POST2005 takes the value 1 when the recommendation announcement is issued in post-IFRS period and 0 otherwise. $E U$ takes the value 1 when the recommendation is issued for mandatory adopters and 0 for the control sample of US firms. FOLL is the natural logarithm of analyst following. DISPERSION is calculated as the standard deviation of all annual earnings forecasts issued before the recommendation month. AVG_SURPRISE is the absolute value of the percentage difference between actual earnings and the most recent consensus earnings forecast. TOPBROKER takes the value 1 if the recommendation is issued by one of the top 10 brokerage firms, and 0 otherwise. EXPERIENCE is measured as the number of years in which the analyst issuing the recommendation revision has issued at least one earnings forecast for the firm. $R E C_{-} C D$ is the IBES level of recommendation ranging from 1 to 5 with 1 indicating a strong buy and 5 a strong sell. SAME_EPS_CH takes the value 1 if the recommendation announcement is made on the same day with an EPS forecast revision in the same direction. MOMENTUM is the compounded market adjusted return in a 90-day period before the recommendation. $M_{-} B$ is the ratio of market value to book value of equity. SIZE is the natural logarithm of total assets. Errors are clustered by recommendation date. Second row shows p-values. Significance levels of $1 \%, 5 \%$ and $10 \%$ are indicated by ${ }^{\mathrm{a}},{ }^{\mathrm{b}}$ and ${ }^{\mathrm{c}}$ respectively.

\begin{tabular}{|c|c|c|}
\hline & Upgrades & Downgrades \\
\hline \multirow[t]{2}{*}{ POST2005 } & 0.00191 & 0.00078 \\
\hline & 0.27 & 0.73 \\
\hline \multirow{2}{*}{$E U$} & $0.00979^{\mathrm{b}}$ & $0.02175^{\mathrm{c}}$ \\
\hline & 0.04 & 0.08 \\
\hline \multirow[t]{2}{*}{$P O S T 2005^{*} E U$} & $0.00413^{c}$ & $-0.01404^{\mathrm{a}}$ \\
\hline & 0.06 & 0.01 \\
\hline \multirow[t]{2}{*}{$F O L L$} & 0.00055 & $-0.00391^{\mathrm{b}}$ \\
\hline & 0.66 & 0.02 \\
\hline \multirow[t]{2}{*}{ DISPERSION } & -0.00016 & -0.00009 \\
\hline & 0.40 & 0.50 \\
\hline \multirow[t]{2}{*}{ AVG_SURPRISE } & 0.00023 & -0.00015 \\
\hline & 0.33 & 0.69 \\
\hline \multirow[t]{2}{*}{ TOPBROKER } & $0.00584^{\mathrm{a}}$ & -0.00081 \\
\hline & 0.01 & 0.57 \\
\hline \multirow[t]{2}{*}{ EXPERIENCE } & $0.00072^{\mathrm{a}}$ & -0.00002 \\
\hline & 0.01 & 0.93 \\
\hline \multirow[t]{2}{*}{$R E C \_C D$} & $-0.00535^{\mathrm{a}}$ & $-0.00453^{\mathrm{a}}$ \\
\hline & 0.01 & 0.01 \\
\hline \multirow[t]{2}{*}{ SAME_EPS_CH } & $0.02192^{\mathrm{a}}$ & $-0.03205^{\mathrm{a}}$ \\
\hline & 0.01 & 0.01 \\
\hline \multirow[t]{2}{*}{ MOMENTUM } & 0.00159 & $0.03015^{\mathrm{a}}$ \\
\hline & 0.67 & 0.01 \\
\hline \multirow[t]{2}{*}{$M \_B$} & $0.00069^{b}$ & $0.00138^{\mathrm{b}}$ \\
\hline & 0.03 & 0.02 \\
\hline \multirow[t]{2}{*}{ SIZE } & $-0.00465^{\mathrm{a}}$ & $0.00751^{\mathrm{a}}$ \\
\hline & 0.01 & 0.01 \\
\hline Country Effects & YES & YES \\
\hline Industry effects & YES & YES \\
\hline $\mathrm{N}$ & 11757 & 11387 \\
\hline Adj. R-Sq & 0.0709 & 0.1374 \\
\hline
\end{tabular}

